\title{
ANALISIS PERBANDINGAN KINERJA KEUANGAN PERUMDA BPR BANK CIREBON SEBELUM DAN SESUDAH PENGUMUMAN PANDEMI COVID-19 \\ Oleh :
}

Putri Agustina

Politeknik Piksi Ganesha, (Administrasi Keuangan)

Email : pagustina@piksi.co.id

Siti Nurmeniar Said

Politeknik Piksi Ganesha, (Administrasi Keuangan)

Email : snsaid@piksi.co.id

\begin{tabular}{ll}
\hline Article Info & Abstract \\
\cline { 2 - 2 } Article History: & The purpose of this study was to determine the financial \\
Received 18 August - 201 & performance of Perumda BPR Bank Cirebon before and after the \\
Accepted O2 Sept-2021 & Covid-19 pandemic. The research method used is descriptive \\
Available Online & comparative using secondary data in the form of financial reports \\
25 Sept-2021 & for the period January 2019 to December 2020. The research \\
variable is financial performance with financial ratio indicators, \\
namely Current Ratio, Quick Ratio, Operational Costs and \\
Operational Income (BOPO), Return on Assets (ROA), Return On \\
Equity (ROE), Debt to Assets Ratio (DAR). The results of this study \\
indicate that several indicators of financial performance in \\
Perumda BPR Bank Cirebon have increased and decreased. The \\
highest growth is found in the profitability ratio indicator, namely \\
Return On Equity. This proves that the financial condition of \\
Perumda BPR Cirebon during the pandemic period is quite stable.
\end{tabular}

Keyword:

Covid-19, Rural Bank,

Financial Performance,

Financial Ratios.

\section{PENDAHULUAN}

Wabah Covid-19 saat ini sangat mempengaruhi dunia Perbankan di Indonesia. Wabah virus Covid-19 ini tak bisa lagi kita pandang sebelah mata. Hal ini pun telah menjadi tantangan baru bagi dunia industri perbankan di Indonesia, terutama dari sisi penyaluran kredit. Sejumlah bank di Indonesia pun sudah mulai mengambil sikap upaya ekspansi kredit karena kondisi ekonomi global masih bergejolak dengan adanya tekanan dari pandemi Covid-19 pada saat ini. Perbankan ini sangat berperan dalam membantu dunia usaha yang sedang mengalami tekanan baik melalui restrukturisasi kredit yang tidak perlu membeda-bedakan sektor. Namun tantangan utama perbankan saat ini ialah bagaimana menjaga agar kredit tidak macet.

Masa pandemi Covid-19 seperti sekarang ini, pemerintah Indonesia memutuskan untuk mengutamakan tiga sektor, yaitu dalam sektor kesehatan, sektor riil dan perbankan. Pandemi Covid-19 menimbulkan berbagai permasalahan bagi perekonomian, termasuk di dunia usaha yang dapat memunculkan persoalan di dunia perbankan. Hal ini bisa terjadi, karena sektor perbankan merupakan lembaga perantara yang mendukung kebutuhan dana investasi di seluruh dunia usaha.

Masa pandemi Covid-19 ini banyak mempengaruhi perekonomian dari berbagai sektor termasuk pada sektor perbankan, karena pembatasan operasional perbankan di Indonesia dan daya beli masyarakat berkurang karena pembatasan kegiatan perekonomian. (Farild, 2021)

Sedangkan pada BPR saat pandemi seperti ini, BPR masih dalam kondisi yang aman dengan aset yang cukup besar dengan $6,08 \%$ pada bulan 
Mei 2020 dibanding periode tahun 2019 di bulan Mei sebelum pandemi di Indonesia. Ketua umum Perbarindo Joko Suyanto mengatakan bahwa aset BPR sampai bulan Mei 2020 sebesar 145 triliun. Begitu juga dengan penghimpunan dana dan deposit.

Bank Perkreditan Rakyat (BPR) adalah salah satu dari lembaga keuangan yang dalam kegiatan usahanya menggunakan prinsip tersendiri, tidak memberikan jasa dalam pembayaran dalam pengawasannya dipantau langsung oleh OJK, berdasarkan dari UU No. 21 tahun 2011. berdasarkan kepemilikannya BPR terbagi menjadi 2 yaitu milik pemerintah dan BPR milik swasta, sedangkan berdasarkan pengelolaannya BPR terbagi menjadi BPR konvensional dan BPR syariah yang bertugas menerima dana dalam bentuk tabungan dan deposit berjangka dalam kredit, menyediakan pembiayaan, serta menempatkan dananya dalam bentuk SBI, sertifikat deposito, dan di bank lain.

Perumda BPR Bank Cirebon adalah salah satu perusahaan perbankan daerah yang entah itu terpengaruh semakin besar assetnya atau sebaliknya ditengah wabah Covid-19 ini. Peneliti memilih penelitian di Perumda BPR Bank Cirebon, karena Perumda BPR Bank Cirebon merupakan bank daerah yang memiliki misi mendorong pertumbuhan perekonomian daerah dengan memberikan pelayanan terhadap kelompok pengusaha usaha kecil, mikro, dan menengah khususnya di kota Cirebon.

Maka dari itu perlu dilakukan penelitian menganalisis pengaruh Covid-19 terhadap kinerja keuangan perbankan dengan menganalisis laporan keuangan dengan menggunakan rasio keuangan diantaranya rasio likuiditas, rasio profitabilitas , dan rasio solvabilitas. Rasio keuangan digunakan untuk melihat posisi keuangan dan operasi keuangan, serta sebagai gambaran dari keseluruhan kinerja keuangan perusahaan.

Tujuan penelitian ialah untuk membandingkan kinerja keuangan Bank saat sebelum pengumuman wabah Covid-19 dan sesudah pengumuman wabah Covid-19 di Indonesia pada Perumda BPR Bank Cirebon.

\section{KAJIAN PUSTAKA PEGEMBANGAN HIPOTESIS}

DAN

Perbankan adalah penghimpun dalam penyaluran dana masyarakat dan menunjang pembangunan dalam rangka meningkatkan pembangunan pertumbuhan ekonomi dan agar stabil standar kehidupan rakyat Indonesia (Arinta,
2016). Perbankan adalah bank yang kegiatan usahanya berdasarkan prinsip syariah, yang kegiatannya tidak memberikan jasa dalam pengeluaran. (Supeno, 2017)

Bank adalah badan atau organisasi yang memberikan pelayanan dan jasa dengan berbagai jasa keuangan yang dimana aktivitasnya melakukan penerimaan dan pengeluaran pembayaran, tabungan, simpanan giro serta deposito, yang digunakan untuk pinjaman kredit yang ditujukan pada setiap masyarakat. (Sutiman, 2019)

Menurut UU No. 10 tahun 1998, pengertian bank adalah Badan Usaha yang mengumpulkan dana dari masyarakat dengan bentuk tabungan dan memberikannya kepada masyarakat dalam bentuk kredit dan bentuk lainnya dalam rangka meningkatkan standar kehidupan rakyat. Kegiatan Bank yaitu menerima simpanan dari masyarakat yang mempunyai dana kelebihan dalam bentuk giro, tabungan, atau deposito berjangka, lalu memberikan kredit kepada orang atau pihak yang perlu dana dalam usaha.

Salah satu jenis bank konvensional adalah Bank Perkreditan Rakyat, Bank Perkreditan Rakyat merupakan lembaga keuangan bank yang melakukan setiap kegiatan usahanya berdasarkan prinsip syariah dalam kegiatan memberikan jasa. Fungsi dari BPR sendiri adalah untuk mengumpulkan dana dari masyarakat dan menyalurkan ke masyarakat dengan bentuk tabungan, deposito berjangka atau kredit dan menyalurkan kepada masyarakat. (Prananta, 2019). Setiap jenis dalam usaha pasti akan memiliki catatan laporan keuangan untuk mengetahui kondisi keuangan perusahaan tersebut.

Pengertian laporan keuangan adalah catatan informasi keuangan sebuah perusahaan pada suatu periode untuk melihat kondisi keuangan perusahaan dengan menggambarkan kinerja suatu perusahaan.

Tujuan laporan keuangan adalah untuk melihat keuangan perusahaan pada periode tertentu, dan memberikan informasi keuangan perusahaan kepada pihak-pihak yang memiliki kepentingan atau mencari informasi keuangan sebuah perusahaan.

Bentuk laporan keuangan itu sendiri ada berbagai macam jenis diantaranya:

a. Neraca yang digunakan untuk melihat kondisi keuangan perusahaan pada waktu tertentu. 
b. Laporan laba rugi digunakan untuk melihat hasil usaha di dalam perusahaan dalam periode waktu tertentu.

c. Laporan perubahan modal adalah laporan keuangan yang berisi jumlah modal perusahaan dalam waktu periode tertentu.

d. Laporan aliran kas digunakan untuk menunjukan semua kegiatan keuangan apakah berpengaruh langsung atau tidak langsung dengan kas perusahaan tersebut.

e. Laporan catatan keuangan ialah laporan yang memberikan informasi laporan keuangan yang memerlukan sebuah penjelasan tertentu lebih terperinci.

Pengertian analisis laporan keuangan adalah proses untuk mengetahui posisi keuangan secara lebih dalam yang akan diketahui pencapaian target yang telah direncanakan sebelumnya apakah tercapai atau tidak. (Kasmir, 2018)

Rasio Keuangan ialah metode yang sering digunakan untuk mengetahui laporan keuangan untuk mengoreksi kinerja keuangan perusahaan, dan untuk mempermudah dalam mengetahui informasi keuangan perusahaan. (Sanjaya, 2017)

Kinerja keuangan bank adalah sebuah kondisi keuangan bank di suatu periode tertentu yang menyangkut dalam sudut pandang pengumpulan dana atau dalam penyaluran dana yang biasanya diukur dengan kondisi modal bank. (Alinda, 2018). Sedangkan menurut (Fahmi, 2017) Kinerja keuangan adalah suatu analisis keuangan yang dilakukan untuk mengetahui kemampuan perusahaan telah melaksanakan dengan menggunakan aturan penggunaan keuangan secara benar.

\section{METODE PENELITIAN}

Penelitian ini dilakukan langsung di Perumda BPR Bank Cirebon dan data yang digunakan ialah dengan data sekunder yang diperoleh langsung dari Bank BPR berupa laporan tahunan.

Data yang digunakan adalah laporan keuangan Perumda BPR Bank Cirebon yang berupa laporan neraca dan laporan laba rugi pada periode 2019 dan 2020. Dalam penulisan ini untuk mendapatkan data yang dibutuhkan sesuai metode yang digunakan adalah dengan metode deskriptif komparatif dan menggunakan data kuantitatif dengan rasio-rasio untuk menganalisis kinerja keuangan. Dalam penelitian ini juga mengunakan uji statistik deskriptif untuk memperlengkap menganalisis perbedaan kinerja keuangan sebelum pengumuman dan sesudah pengumuman Covid-19 pada perusahaan. (Esomar, 2021)

Komparatif adalah jenis penelitian deskriptif yang membandingkan beberapa variable pada waktu yang berbeda, untuk mencari jawaban dengan mendasar tentang sebab dan akibat, dengan menganalisis penyebab dari terjadinya kejadian. Kuantitatif adalah penelitian ilmiah sistematis terhadap kejadian dari akibat hubungan-hubungannya. Tujuan penelitian kuantitatif yaitu mengembangkan model-model matematis, teori atau hipotesis yang berkaitan dengan kejadian alam.

Uji Statistik Deskriptif adalah analisis statistik yang berupa sebuah gambaran tentang karakteristik dari setiap variable penelitian yang dapat dilihat dari mean (rata-rata), median (nilai tengah), maximum dan minimum. Uji statistik deskriptif dilakukan bertujuan untuk mengetahui dan memperoleh penelitian yang terkait pada data yang digunakan dalam penelitian dari mean, median, nilai minimum, dan nilai maximum (Ghozali, 2016)

Adapun tahapan-tahapan dalam analisis data kinerja keuangan di Permda BPR Bank Cirebon adalah sebagai berikut:

1) Review data dari kinerja keuangan pada Perumda BPR Bank Cirebon. Laporan Keuangan yang terdiri dari laporan Neraca dan laporan Laba Rugi tahun 2019-2020.

2) Perhitungan rasio Likuiditas, Profitabilitas, dan Solvabilitas pada Laporan Keuangan Perumda BPR Bank Cirebon. Perhitungan ini menggunakan rasio keuangan perbankan, yaitu :

1) Rasio Likuiditas.

Yaitu rasio untuk mengetahui kemampuan perusahaan dalam membiayai oprasional dan memenuhi kewajiban financial saat ditagih, dengan menggunakan rasio berikut :

1. Rasio Lancar (Current Rasio) : $\frac{\text { Aktiva Lancar }}{\text { Hutang Lancar }} \times 100 \%$

2. Rasio Cepat (Quick Ratio) :

$\frac{\text { Cash Asset }}{\text { Total Deposito }} \times 100 \%$

1) Rasio Profitabilitas.

Yaitu rasio yang digunakan dalam menilai kemampuan perusahaan untuk memperoleh laba 
perusahaan (Sartika \& Argo, 2020), dengan menggunakan rasio dan rumus berikut :

1. Rasio Biaya Operasional (BOPO) :

Biaya Operasional

Pendapatan Operasional $\times 100 \%$

2. Return On Asset (ROA) :

Laba Bersih

Total Aktiva x $100 \%$

3. Return On Equity (ROE):

$\frac{\text { Laba Bersih }}{\text { Total Ekuitas }} \times 100 \%$

\section{2) Rasio Solvabilitas.}

Yaitu kemampuan perusahaan dalam menilai seberapa besar porsi hutang dalam membiayai aktiva perusahaan, dengan menggunakan rasio berikut :

1. Total Debt to Total Assets Rasio (DAR):

$$
\frac{\text { Total Kewajiban }}{\text { Total Aktiva }} \times 100 \%
$$

3) Membandingkan hasil perhitungan rasio keuangan perbankan dengan membandingkan rasio keuangan Perumda BPR Bank Cirebon, pada tahun 2019 kuartal 1 sampai kuartal 4 dibandingkan dengan kuartal 1 sampai 4 di tahun 2020 .

\section{HASIL DAN PEMBAHASAN}

Rasio Keuangan adalah menganalisis keuangan pada perusahaan untuk melihat kinerja keuangan di suatu perusahaan berdasarkan perbandingan data laporan keuangan di perusahaan. (Rosanna 2021)

Tabel 1. Hasil Perhitungan Rasio Keuangan

\begin{tabular}{|c|c|c|c|c|c|c|c|}
\hline Tahun & Periode & CR & QR & BOPO & ROA & ROE & DAR \\
\hline 2019 & Q1 & $75,02 \%$ & $73,95 \%$ & $87,13 \%$ & $0,40 \%$ & $3,99 \%$ & $89,23 \%$ \\
\hline & Q2 & $79,37 \%$ & $78,29 \%$ & $108,39 \%$ & $0,69 \%$ & $7,11 \%$ & $90,34 \%$ \\
\hline & Q3 & $87,01 \%$ & $85,86 \%$ & $102,58 \%$ & $0,34 \%$ & $3,25 \%$ & $89,51 \%$ \\
\hline & Q4 & $84,63 \%$ & $83,55 \%$ & $96,05 \%$ & $0,47 \%$ & $4,52 \%$ & $89,52 \%$ \\
\hline 2020 & Q1 & $81,00 \%$ & $79,93 \%$ & $95,22 \%$ & $0,14 \%$ & $1,41 \%$ & $89,77 \%$ \\
\hline & Q2 & $84,40 \%$ & $83,28 \%$ & $93,71 \%$ & $0,38 \%$ & $3,66 \%$ & $89,61 \%$ \\
\hline & Q3 & $90,64 \%$ & $89,38 \%$ & $90,31 \%$ & $0,95 \%$ & $8,11 \%$ & $88,34 \%$ \\
\hline & Q4 & $82,17 \%$ & $80,38 \%$ & $89,54 \%$ & $1,27 \%$ & $11,39 \%$ & $88,83 \%$ \\
\hline
\end{tabular}

Sumber : Data diolah, 2021

\section{A. Rasio Lancar (Current Rasio/CR)}

Current Rasio atau rasio lancar adalah rasio keuangan yang digunakan untuk membandingkan aktiva lancar dengan utang lancar disuatu pe rusahaan. Dalam Current Rasio jika interprestasinya semakin besar, maka akan semakin bagus.

\section{CR 2019}

$\mathrm{Q} 1=\frac{155.355 .017}{207.074 .417} \times 100 \%=75,02 \%$
$\mathrm{Q} 2=\frac{164.004 .249}{206.644 .120} \times 100 \%=79,37 \%$
$\mathrm{Q} 3=\frac{170.231 .794}{195.657 .458} \times 100 \%=87,01 \%$
$\mathrm{Q} 4=\frac{179.122 .498}{211.649 .003} \times 100 \%=84,63 \%$

Berdasarkan tabel dan perhitungan rasio lancar terlihat Q1 sebelum adanya covid-19 pada
CR 2020
Q1 $=\frac{178.710 .430}{220.634 .767} \times 100 \%=81,00 \%$
Q2 $=\frac{180.627 .597}{214.006 .144} \times 100 \%=84,40 \%$
Q3 $=\frac{178.670 .620}{197.120 .961} \times 100 \%=90,64 \%$
Q4 $=\frac{176.164 .112}{214.398 .326} \times 100 \%=82,17 \%$

tahun 2019 sebesar 75,02\% sedangkan Q1 pada tahun 2020 sesudah adanya covid-19 adalah 
81,00\%. Q2 pada tahun 2019 sebesar 79,37\% dan Q2 pada tahun 2020 sebesar $84,40 \%$. Q3 pada tahun 2019 sebesar 87,01\% sedangkan Q3 pada tahun 2020 adalah 90,64\%. Dan untuk Q4 pada tahun 2019 adalah sebesar 84,63\% sedangkan pada 2020 Q4 sebesar $82,17 \%$. Terlihat dari data tersebut untuk semua data mengalami kenaikan kecuali pada Q4 yang mengalami penurunan sebesar $2,46 \%$. Dilihat dari penjelasan tersebut maka interprestasi untuk Current Rasio pada Perumda BPR Bank Cirebon bagus karena mengalami kenaikan, yang berarti perusahaan mampu memenuhi kewajibannya..

Tabel 2. Statistik Deskriptif Current Rasio

\begin{tabular}{|c|c|c|c|c|c|}
\hline Tahun & $\mathbf{N}$ & Mean & Median & Minimum & Maximum \\
\hline $\mathbf{2 0 1 9}$ & 4 & 0,815075 & 0,82 & 0,7502 & 0,8701 \\
\hline $\mathbf{2 0 2 0}$ & 4 & 0,845525 & 0,83285 & 0,81 & 0,9064 \\
\hline
\end{tabular}

Sumber : Data diolah, 2021

Berdasarkan tabel 2. Analisis Current Ratio 2019 memiliki nilai minimum 0,7502 sedangkan tahun 2020 sebesar 0,81 . nilai maksimum 0,8701 di tahun 2019 sedangkan di 2020 senilai 0,8701. Di tahun 2019 rata-rata sebesar 0,81508 dan di tahun 2020 sebesar 0,84553 sedangkan pada median pada tahun 2019 sebesar 0,82 dan 0,83285 di tahun 2020. Dapat di definisikan adanya variasi dari current ratio tersebut dilihat dari angka nilai maksimum yang lebih besar dari pada nilai yang lain sedangkan dalam peningkatan dari semua kategori terlihat semuanya mengalami kenaikan dari 2019 ke 2020.

\section{B. Rasio Cepat (Quick Rasio/QR)}

Quick Rasio atau rasio cepat adalah rasio keuangan yang digunakan untuk mengukur kemampuan perusahan dalam membayar kewajibannya dengan aktiva lancar (cash asset). Dalam Quick Rasio jika interprestasinya semakin besar, maka hasilnya akan semakin bagus.

QR 2019

$$
\mathrm{Q} 1=\frac{153.127 .839}{207.074 .417} \times \quad 100 \%=73,95 \%
$$$$
\text { Q2 }=\frac{161.777 .071}{206.644 .120} \times 100 \%=78,29 \%
$$$$
\text { Q3 }=\frac{167.985 .559}{195.657 .458} \times 100 \%=85,86 \%
$$$$
\mathrm{Q} 4=\frac{176.834 .997}{211.649 .003} \times 100 \%=83,55 \%
$$

Berdasarkan tabel dan perhitungan rasio cepat terlihat Q1 sebelum adanya cobid-19 pada tahun 2019 sebesar 73,95\% sedangkan Q1 pada tahun 2020 sesudah adanya covid-19 adalah $79,93 \%$. Q2 pada tahun 2019 sebesar 78,29\% dan Q2 pada tahun 2020 sebesar $83,28 \%$. Q3 pada tahun 2019 sebesar $85,86 \%$ sedangkan Q3 pada tahun 2020 adalah 89,38\%. Dan untuk Q4 pada tahun 2019 adalah sebesar $83,55 \%$ sedangkan pada 2020 Q4 sebesar $80,93 \%$. Terlihat dari data tersebut untuk semua rasio cepat mengalami kenaikan kecuali pada Q4 yang mengalami penurunan sebesar $2,62 \%$. Dilihat dari penjelasan tersebut maka
QR 2020

$\mathrm{Q} 1=\frac{176.352 .706}{220.634 .767} \times 100 \%=79,93 \%$

Q2 $=\frac{178.229 .866}{214.006 .144} \times 100 \%=83,28 \%$

Q3 $=\frac{176.180 .371}{197 \cdot 120.961} \times \quad 100 \%=89,38 \%$

$\mathrm{Q} 4=\frac{173.517 .302}{214.398 .326} \times \quad 100 \%=80,93 \%$

interprestasi untuk Quick Ratio pada Perumda BPR Bank Cirebon bagus karena mengalami kenaikan, yang berarti aktiva lancar pada perusahaan stabil dan dapat membayar hutang perusahaan. 
Tabel 3. Statistik Deskriptif Quick Rasio

\begin{tabular}{|c|c|c|c|c|c|}
\hline Tahun & $\mathbf{N}$ & Mean & Median & Minimum & Maximum \\
\hline $\mathbf{2 0 1 9}$ & 4 & 0,804125 & 0,8092 & 0,7395 & 0,8586 \\
\hline $\mathbf{2 0 2 0}$ & 4 & 0,832425 & 0,8183 & 0,7993 & 0,8938 \\
\hline
\end{tabular}

Sumber : Data diolah, 2021

Berdasarkan tabel 3. Analisis Quick Ratio memiliki nilai minimun sebesar 0,7395 di tahun 2019 dan 0,7993 di tahun 2020. nilai maksimum ditahun 2019 0,8586 dan di tahun 2020 sebesar 0,8938 . nilai mean 0,80413 pada tahun 2019 dan 0,83243 ditahun 2020. dan median senilai 0,8092 ditahun 2019 sedangkan pada tahun 2020 senilai 0,8183 . Dapat didefinisikan dari adanya variasi dari quick ratio tersebut dilihat dari nilai maximum lagi yang memiliki nilai lebih besar dari yang lain. Sedangkan nilai keseluruhan dari 2019 terhadap 2020 mengalami peningkatan.

\section{Rasio Biaya Operasional (BOPO)}

BOPO adalah rasio keuangan yang digunakan untuk melihat seberapa besar kemampuan perusahaan dalam mengelola beban operasionalnya dengan membandingkan beban operasional dengan pendapatan operasional. Dalam BOPO jika interprestasinya mengalami kenaikan atau semakin besar, maka hasilnya akan kurang bagus karna beban oprasional yang dikeluarkan lebih besar dibandingkan pendapatan.

$$
\begin{aligned}
& \text { BOPO } 2019 \\
& \mathrm{Q} 1=\frac{7.621 .370}{8.746 .871} \times 100 \%=87,13 \% \\
& \mathrm{Q} 2=\frac{20.068 .556}{18.514 .745} \times 100 \%=108,39 \% \quad \mathrm{Q} 2=\frac{17.120 .639}{18.269 .743} \times 100 \%=93,71 \% \\
& \mathrm{Q} 3=\frac{28.532 .429}{27.815 .693} \times 100 \%=102,58 \% \quad \mathrm{Q} 3=\frac{25.475 .041}{28.209 .925} \times 100 \%=90,31 \% \\
& \mathrm{Q} 4=\frac{37.053 .975}{38.576 .118} \times 100 \%=96,05 \% \quad \mathrm{Q} 4=\frac{34.265 .271}{38.267 .918} \times 100 \%=89,54 \% \\
& \mathrm{Q} 1=\frac{8.495 .330}{8.922 .225} \times 100 \%=95,22 \%
\end{aligned}
$$

Berdasarkan tabel dan perhitungan BOPO terlihat Q1 sebelum adanya cobid-19 pada tahun 2019 sebesar $87,13 \%$ sedangkan Q1 pada tahun 2020 sesudah adanya covid-19 adalah 95,22\%. Q2 pada tahun 2019 sebesar 108,39\% dan Q2 pada tahun 2020 sebesar $93,71 \%$. Q3 pada tahun 2019 sebesar 102,58\% sedangkan Q3 pada tahun 2020 adalah $90,31 \%$. Dan untuk Q4 pada tahun 2019 adalah sebesar 96,05\% sedangkan pada

2020 Q4 sebesar 89,54\%. Terlihat dari data tersebut untuk semua data perhitungan BOPO mengalami penurunan kecuali pada Q1 yang mengalami kenaikan sebesar 8,09\%. Dilihat dari penjelasan tersebut interprestasi BOPO mengalami penurunan yang berarti bank bisa lebih efektif dan efisien dalam mengelola beban operasional.

Tabel 4. Statistik Deskriptif Rasio Biaya Operasional (BOPO)

\begin{tabular}{|c|c|c|c|c|c|}
\hline Tahun & $\mathbf{N}$ & Mean & Median & Minimum & Maximum \\
\hline $\mathbf{2 0} 19$ & 4 & 0,985375 & 0,99315 & 0,8713 & 1,0839 \\
\hline $\mathbf{2 0} 20$ & 4 & 0,92195 & 0,9201 & 0,8954 & 0,9522 \\
\hline
\end{tabular}

Sumber : Data diolah, 2021

Berdasarkan tabel 4. Analisis BOPO 2019 memiliki nilai minimum 0,8713 sedangkan tahun 2020 sebesar 0,8954 . nilai maksimum 1,0839 di tahun 2019 sedangkan di 2020 senilai 0,9522. Di tahun 2019 mean sebesar 0,98538 dan di tahun 2020 sebesar 0,92195 sedangkan median pada tahun 2019 sebesar 0,99315 dan 0,9201 di tahun
2020. Dapat di definisikan adanya variasi dari BOPO tersebut dilihat dari angka nilai maksimum lebih besar dari pada nilai yang lain sedangkan dalam peningkatan dari tahun ke tahun hanya nilai minimum saja yang mengalami kenaikan sedangkan yang lain mengalami penurunan. 
D. Return On Asset (ROA)

ROA atau Return On Asset adalah rasio keuangan yang digunakan untuk melihat kemampuan perusahaan dalam memperoleh laba dari aktiva yang digunakan perusahaan. Dalam ROA dikategorikan bagus apabila interprestasinya meningkat atau mengalami kenaikan.

$$
\begin{aligned}
& \text { ROA } 2019 \\
& \mathrm{Q} 1=\frac{918.304}{232.063 .561} \times 100 \%=0,40 \% \\
& \mathrm{Q} 2=\frac{1.571 .577}{228.740 .284} \times 100 \%=0,69 \% \\
& \text { Q3 }=\frac{745.261}{218.579 .938} \times 100 \%=0,34 \% \\
& \mathrm{Q} 4=\frac{1.121 .414}{236.438 .158} \times 100 \%=0,47 \% \\
& \begin{array}{l}
\text { Q1 }=\frac{354.243}{245.778 .165} \times 100 \%=0,14 \% \\
\text { Q2 }=\frac{908.256}{238.825 .648} \times 100 \%=0,38 \% \\
\text { Q3 }=\frac{2.109 .422}{223.135 .757} \times 100 \%=0,95 \% \\
\text { Q4 }=\frac{3.070 .270}{241.360 .622} \times \quad 100 \%=1,27 \%
\end{array}
\end{aligned}
$$

Berdasarkan tabel dan perhitungan ROA terlihat Q1 sebelum adanya cobid-19 pada tahun 2019 sebesar 0,40\% sedangkan Q1 pada tahun 2020 sesudah adanya covid-19 adalah $0,14 \%$. Q2 pada tahun 2019 sebesar 0,69\% dan Q2 pada tahun 2020 sebesar $0,38 \%$. Q3 pada tahun 2019 sebesar 0,34\% sedangkan Q3 pada tahun 2020 adalah 0,95\%. Dan untuk Q4 pada tahun 2019

adalah sebesar 0,47\% sedangkan pada 2020 Q4 sebesar $1,27 \%$. Terlihat dari data ROA tersebut untuk Q1 dan Q2 mengalami penurunan sedangkan untuk Q3 dan Q4 mengalami kenaikan. Dari penjelasan tersebut terlihat untuk ROA interprestasinya sama. dua mengalami kenaikan dan dua mengalami penurunan.

Tabel 5. Statistik Deskriptif Return On Asset (ROA)

\begin{tabular}{|c|c|c|c|c|c|}
\hline Tahun & $\mathbf{N}$ & Mean & Median & Minimum & Maximum \\
\hline $\mathbf{2 0 1 9}$ & 4 & 0,00475 & 0,00435 & 0,0034 & 0,0069 \\
\hline $\mathbf{2 0 2 0}$ & 4 & 0,00685 & 0,00665 & 0,0014 & 0,0127 \\
\hline
\end{tabular}

Sumber : Data diolah, 2021

Berdasarkan tabel 5. Analisis ROA 2019 memiliki nilai minimum 0,0034 sedangkan tahun 2020 sebesar 0,0014. nilai maksimum 0, 0069 di tahun 2019 sedangkan di 2020 senilai 0,0127. Di tahun 2019 mean sebesar 0,00475 dan di tahun 2020 sebesar 0,00685 . sedangkan pada median pada tahun 2019 sebesar 0,00435 dan $0,00665 \mathrm{di}$ tahun 2020. Dapat di definisikan adanya variasi dari ROA tersebut dilihat dari angka nilai mean yang lebih besar dari pada nilai yang lain. sedangkan dalam peningkatan dari semua kategori terlihat semuanya mengalami kenaikan dari 2019 terhadap 2020 hanya nilai minimum saja yang mengalami penurunan.

\section{E. Return On Equity (ROE)}

ROE atau Return On Equity adalah rasio keuangan yang digunakan untuk mengukur kemampuan perusahaa untuk menghasilkan laba dari investasi pemegang saham di suatu perusahaan. Dalam ROE dikategorikan bagus jika interprestasinya mengalami kenaikan.

\section{ROE 2019}

$$
\begin{aligned}
& \mathrm{Q} 1=\frac{918.304}{22.989 .144} \times \quad 100 \%=3,99 \%, \mathrm{Q} 1=\frac{354.243}{25.143 .398} \times 100 \%=1,41 \% \\
& \mathrm{Q} 2=\frac{1.571 .577}{22.096 .164} \times 100 \%=7,11 \% \\
& \mathrm{Q} 3=\frac{745.261}{22.922 .480} \times 100 \%=3,25 \% \\
& \mathrm{Q} 2=\frac{908.256}{24.819 .504} \times 100 \%=3,66 \% \\
& \mathrm{Q} 4=\frac{1.121 .414}{24.789 .155} \times 100 \%=4,52 \% \\
& \mathrm{Q} 4=\frac{2.109 .422}{26.014 .796} \times 100 \%=8,11 \%
\end{aligned}
$$


Berdasarkan tabel dan perhitungan ROE terlihat Q1 sebelum adanya covid-19 pada tahun 2019 sebesar 3,99\% sedangkan Q1 pada tahun 2020 sesudah adanya covid-19 adalah 1,41\%. Q2 pada tahun 2019 sebesar 7,11\% dan Q2 pada tahun 2020 sebesar 3,66\%. Q3 pada tahun 2019 sebesar $3,25 \%$ sedangkan Q3 pada tahun 2020 adalah $8,11 \%$. Dan untuk Q4 pada tahun 2019 adalah sebesar 4,25\% sedangkan pada 2020 Q4 sebesar $11,39 \%$. Terlihat dari data ROE tersebut untuk Q1 dan Q2 mengalami penurunan sedangkan Q3 dan
Q4 mengalami kenaikan dari tahun 2019 ke tahun 2020. Dari penjelasan tersebut ROE memiliki interprestasi sama dengan ROA. Dua interprestasinya bagus dan dua lagi buruk karna mengalami penurunan.Yang menarik adalah kondisi pada Q4 secara Year on Year mengalami peningkatan sebesar $152 \%$. Hal ini menunjukkan bahwa kemapuan perusahaan dalam menghasilan keuntungan dengan modal sendiri yang dimiliki sudah baik walaupun dalam masa pandemi.

Tabel 6. Statistik Deskriptif Return On Equity (ROE)

\begin{tabular}{|c|c|c|c|c|c|}
\hline Tahun & $\mathbf{N}$ & Mean & Median & Minimum & Maximum \\
\hline $\mathbf{2 0 1 9}$ & 4 & 0,047175 & 0,04255 & 0,0325 & 0,0711 \\
\hline $\mathbf{2 0 2 0}$ & 4 & 0,061425 & 0,05885 & 0,0141 & 0,1139 \\
\hline
\end{tabular}

Sumber : Data diolah, 2021

Berdasarkan tabel 6. Analisis ROE 2019 memiliki nilai minimum 0,0325 sedangkan tahun 2020 sebesar 0,0141 . nilai maksimum 0,0711 di tahun 2019 sedangkan di 2020 senilai 0,1139. Di tahun 2019 mean sebesar 0,04718 dan di tahun 2020 sebesar 0,06143 . sedangkan pada median pada tahun 2019 sebesar 0,04255 dan 0,05885 di tahun 2020. Dapat di definisikan adanya variasi dari ROE tersebut dilihat dari angka nilai mean yang lebih besar dari pada nilai yang lain sedangkan dalam peningkatan dari semua kategori terlihat semuanya mengalami kenaikan kecuali nilai minimum yang mengalami penurunan dari 2019 ke 2020.

\section{F. Debt to Total Assets Rasio (DAR)}

DAR atau Debt to Asset Ratio adalah salah satu rasio keuangan yang digunakan untuk mengukur kemampuan perusahaan yang dibiayai oleh utang dan kemampuan perusahaan dalam memenuhi kewajibannya dengan aktiva yang dimiliki. Dalam DAR jika interprestasinya semakin besar, maka itu tidak akan bagus karna sangat beresiko.

$$
\begin{aligned}
& \text { DAR } 2019 \\
& \mathrm{Q} 1=\frac{207.074 .417}{232.063 .561} \times \quad 100 \%=89,23 \% \\
& \mathrm{Q} 2=\frac{206.644 .120}{228.740 .284} \times 100 \%=90,34 \% \\
& \mathrm{Q} 3=\frac{195.657 .458}{218.579 .938} \times 100 \%=89,51 \% \\
& \mathrm{Q} 4=\frac{211.649 .003}{236.438 .158} \times 100 \%=89,52 \%
\end{aligned}
$$

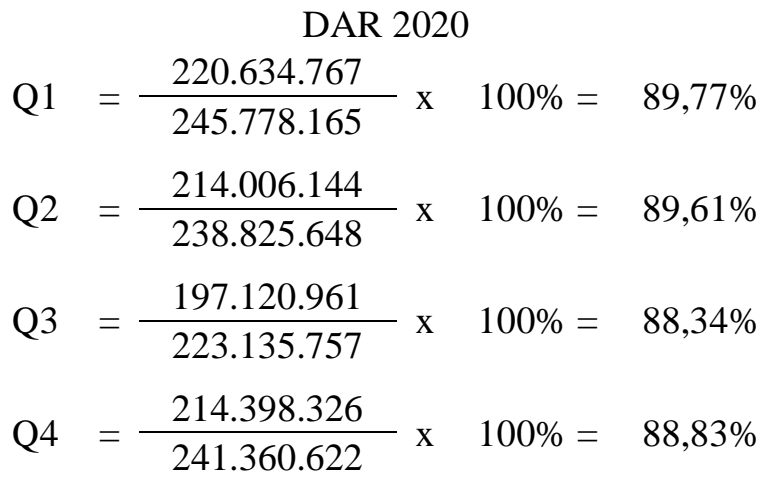

Berdasarkan tabel dan perhitungan DAR terlihat Q1 sebelum adanya cobid-19 pada tahun 2019 sebesar 89,23\% sedangkan Q1 pada tahun 2020 sesudah adanya covid-19 adalah $89,77 \%$. Q2 pada tahun 2019 sebesar 90,34\% dan Q2 pada tahun 2020 sebesar $89,61 \%$. Q3 pada tahun 2019 sebesar $89,51 \%$ sedangkan Q3 pada tahun 2020 adalah 88,34\%. Dan untuk Q4 pada tahun 2019 adalah sebesar $89,52 \%$ sedangkan pada 2020 Q4 sebesar $88,83 \%$. Terlihat dari data DAR tersebut untuk semua data mengalami penurunan meskipun hanya sedikit tetapi pada Q1 mengalami kenaikan sebesar 0,54\%. Dari penjelasan tersebut, terlihat jika DAR resiko keuangannya mengalami penurunan. 
Tabel 7. Statistik Deskriptif Debt to Assets Rasio (DAR):

\begin{tabular}{|c|c|c|c|c|c|}
\hline Tahun & $\mathbf{N}$ & Mean & Median & Minimum & Maximum \\
\hline $\mathbf{2 0 1 9}$ & 4 & 0,8965 & 0,89515 & 0,8923 & 0,9034 \\
\hline $\mathbf{2 0 2 0}$ & 4 & 0,891375 & 0,8922 & 0,8834 & 0,8977 \\
\hline
\end{tabular}

Sumber : Data diolah, 2021

Berdasarkan tabel 7. Analisis Debt To Asseta 2019 memiliki nilai minimum 0,8923 sedangkan tahun 2020 sebesar 0,8834 . nilai maksimum 0 , 9034 di tahun 2019 sedangkan di 2020 senilai 0,8977. Di tahun 2019 mean sebesar 0,8965 dan di tahun 2020 sebesar 0,89138 sedangkan pada median pada tahun 2019 sebesar 0,89515 dan 0,8922 di tahun 2020. Dapat di definisikan adanya variasi dari Debt To Assets tersebut dilihat dari angka nilai maksimum yang lebih besar dari pada nilai yang lain sedangkan dalam peningkatan dari semua kategori terlihat hanya nilai mean yang mengalami kenaikan sedangkan yang lain mengakami penurunan dari tahun 2019 ke tahun 2020.

\section{KESIMPULAN}

Dari hasil penelitian yang telah dijelaskan diatas, maka dapat diambil kesimpulan bahwa kinerja keuangan di Perumda BPR Bank Cirebon tidak terlalu berpengaruh selama Covid-19. Kondisi keuangan dari sebelum pandemi Covid19 sampai adanya pandemik Covid-19 tidak begitu mengalami penurunan. Namun terjadi kenaikan atau peningkatan walaupun hanya sedikit, karena selama pandemi Covid-19 masyarakat membutuhkan dana usaha untuk memenuhi sadang, pangan dan papan. Sehingga mengarahkan masyarakat untuk meminjam kredit kepada Perumda BPR Bank Cirebon.

Hasil dari analisis rasio likuiditas, kinerja keuangan Perumda BPR Bank Cirebon pada sebelum pandemi Covid-19 tahun 2019, hingga adanya pandemi Covid-19 pada tahun 2020, Current Rasio dengan rata-rata $81,50 \%$ di tahun 2019 dan 84,55\% di tahun 2020. Quick Rasio dengan rata-rata $80,41 \%$ di tahun 2019 dan ratarata $83,24 \%$ di tahun 2020. Dapat disimpulkan kinerja keuangan Perumda BPR Bank Cirebon masih dalam keadaan baik karena dilihat secara keseluruhan mengalami peningkatan di tahun 2020 pada saat pandemic Covid-19, yang berarti aktiva lancar pada perusahaan stabil dan dapat membayar hutang perusahaan.

Hasil dari analisis rasio profitabilitas, kinerja keuangan Perumda BPR Bank Cirebon pada sebelum pandemi Covid-19 tahun 2019, hingga adanya pandemi Covid-19 pada tahun 2020,
BOPO dapat dikatakan baik, karena rata-rata 98,53\% di tahun 2019 dan $92,19 \%$ di tahun 2020 . ROA dengan rata-rata $0,47 \%$ di tahun 2019 dan rata-rata $0,68 \%$ di tahun 2020 . ROE dengan ratarata $4,71 \%$ dan rata-rata $6,14 \%$ di tahun 2020 . Dapat disimpulkan kinerja keuangan Perumda BPR Bank Cirebon masih dalam keadaan baik karena dilihat secara keseluruhan mengalami peningkatan di tahun 2020. Terlebih lagi ROE secara Year on Year di Q4 mengalami pertumbuhan yang sangat berarti, yaitu sebesar $152 \%$.

Hasil dari analisis rasio likuiditas, kinerja keuangan Perumda BPR Bank Cirebon pada sebelum pandemi Covid-19 tahun 2019, hingga adanya pandemi Covid-19 pada tahun 2020, DAR dengan rata-rata $89,65 \%$ di tahun 2019 dan $89,15 \%$ di tahun 2020. Dapat disimpulkan kinerja keuangan Perumda BPR Bank Cirebon masih dalam keadaan baik karena dilihat secara keseluruhan mengalami penurunan di tahun 2020, yang berarti semakin berkurang perusahaan menggunakan utang untuk membiayai aktiva perusahaan.

\section{REFERENSI}

Alinda, P. D. \& K. H. (2018). Analisis Kinerja Keuangan Bank Perkreditan Rakyat di Wilayah Malang Raya. Jurnal Ilmu Ekonomi, 2, 419-427.

Arinta, Y. N. (2016). Analisis Perbandingan Kinerja Keuangan antara Bank Syariah dan Bank Konvensional (Studi Kasus pada Bank Syariah Mandiri dan Bank Mandiri). Muqtasid: Jurnal Ekonomi Dan Perbankan $\begin{array}{lll}\text { Syariah, } & 7(1), & 119 .\end{array}$ https://doi.org/10.18326/muqtasid.v7i1.119 $-140$

Esomar, M. (2021). Analisa Dampak Covid-19 terhadap Kinerja Keuangan Perusahaan Pembiayaan di Indonesia. Jurnal Bisnis, Manajemen, Dan Ekonomi, 2(2), 22-29. https://doi.org/10.47747/jbme.v2i2.217

Fahmi, I. (2017). Analisis Kinerja Keuangan. Alfabeta.

Farild, M., Bachtiar, F., Wahyudi, \& Jannah., R. (2021). Analisis Kinerja Keuangan PT. BNI 
Syariah TBK Sebelum dan Pada Saat Pandemi COVID-19. Jurnal Ekonomi, Manajemen \& Akuntansi, 11(1), 88-95.

Ghozali, I. (2016). Aplikasi Analisis Multivariate Dengan Program SPPSS 23. Badan Penerbit Universitas Diponegoro.

Kasmir. (2018). Analisis Laporan Keuangan. Rajawali Pers.

Purba, Rosanna; Renika Hasibuan; Prananda Akbar Syam. (2021). Analisis Rasio Keuangan Untuk Mengukur Kinerja Keuangan Pada PT . Pelabuhan Indonesia I ( Persero ) Periode 2013-2017. xx, 545555.

Prananta, W., Yulianti, Y., \& Damajanti, A. (2019). Pengaruh Kinerja Keuangan Terhadap Penyaluran Kredit Pada Bank Perkreditan Rakyat Di Kota Semarang. Jurnal Riset Ekonomi Dan Bisnis, 12(2), 99. https://doi.org/10.26623/jreb.v12i2.1544

Sanjaya, Surya. (2017). Analisis Du Pont System Dalam Mengukur Kinerja Keuangan PT. TASPEN (Persero). Jurnal Riset Akuntansi dan Bisnis, 17 (1), 15-32.

Sartika, T., \& Argo, putra prima. (2020). Pengaruh Rasio Keuangan Terhadap Profitabilitas Pada Bank Perkreditan Rakyat Di Kota Batam. Jurnal Akrab Juara, 5(3), 101-117.

Supeno, W. (2017). Analisis Kinerja Penghimpunan Dana dalam Meningkatkan Penyaluran Kredit pada Bank Perkreditan Rakyat. Jurnal Moneter, IV(oktober), 121131.

http://ejournal.bsi.ac.id/ejurnal/index.php/ moneter/article/view/2336

Sutiman. (2019). Analisis Rasio ROA dan ROE Dalam Menilai Tingkat Kesehatan Pada PT Bank Mandiri ( PERSERO ) Tbk Tahun 2012 - 2017. Jurnal Mandiri, 3(1), 20-36. 